\title{
Steady flow Analysis of Gurupura River Using Hec-Ras Software
}

\author{
Mr Edwin Issac ${ }^{2}$, Mr Pavan $\mathrm{Raj}^{2}$, Mr Prashanth ${ }^{2}$, Mr Rudresh M Arer $^{2}$ and Ms Apoorva K V ${ }^{1}$ \\ ${ }^{1}$ Assistant Professor, Department of Civil Engineering, SJEC, Mangaluru Karnataka (apoorvak@sjec.ac.in) \\ ${ }^{2}$ UG Students, Department of Civil Engineering, SJEC, Mangaluru Karnataka (prashanth2621998@gmail.com)
}

\begin{abstract}
Flood is overflow of water which has devastating effect on society, environment and economy. It is important to study the scenarios of depth and the extent that water flows out of its boundary conditions. The present study focuses on finding the depth of water level. In this study, Gurupura River is selected to perform steady flow analysis. The hydraulic model HEC-RAS along with GIS tools is used to perform steady flow analysis. For the input of maximum discharge, from results it is observed that the area near the river basin is safe from flood effects.
\end{abstract}

Keywords - Hydraulic model, Steady flow analysis, HEC-RAS, Gurupura River and GIS tools.

\section{INTRODUCTION}

In India, rainfall is the principal form of precipitation. The rainfall is drained off from the catchment through a surface channel called as runoff. When this runoff overflows, submerges the surrounding land leading to occurrence of flood. It is important to study the scenarios of depth and the extent that water flows out of its boundary conditions. Steady flow is the condition where the depth and velocity at particular channel location do not change with respect to time. Flood is dangerous to life and this may damage big amount of properties. Hence flood plain mapping and flood analysis has to be done in order take precautionary measures in advance. In this present study we have used HEC-RAS software for flood analysis.

HEC-RAS is a hydraulic model developed by hydrologic Engineering Centre (HEC) of the US Army Corps of Engineers. It is open source software and analyses the flood from the basin with different discharge condition for the urban area, and determines water surface elevation.

\section{LITERATURE REVIEW}

Anant D. Patel et.al., (2016) conducted a study of flood modelling using HEC RAS and Geo Informatics Technology in lower reaches of Shetrunji river, Gujarat, India. The main scope of the study was to understand the flood hydrology and also to reduce the damage caused in the downstream of the Shetrunji dam. They developed different water surface profile and they were studied using HEC RAS model with Remote Sensing and GIS technology. It has been found that the flood would be generated when the discharge from the dam raises more than 2000 cumecs.

Goodellet et. al., (2006) examined the steps required to perform a flood inundation mapping using HECRAS for Backlick Run River (W.C) and evaluated the capabilities of HEC-RAS and HEC-GeoRAS. The input for this process was cross section data which is extracted from the DEM using ARC-GIS tools then the geometry can be entered into the model and at all upstream boundaries flow data is entered and post processing is done. And they found that HEC-RAS along with HEC-GeoRAS extension can be used to develop flood plain maps. They compared flood frequency events for 1 year and 100 year floods.

Amina Azouaghet et. al., (2018) studied on Floods Modeling of Martil River (Northern Morocco) by integrating of GIS and HEC-RAS. By using HEC-RAS modelling method which helped in calculating variables, depths, water levels, and flow velocities at different locations of the site and different crosssectional zones along Martil River. Hence this work represents the flood mapping of that area and it also classifies risk areas using Geo RAS and HEC-RAS hydraulic modelling tools integrated into the Arc GIS. By their work they have got aerial photographs which depicts knowledge of morphology and river physical characteristics, this helps in taking decision to prevent flood in Tetaun.

Kedric Curtis P et. al., (2016) studied on the topic Logan river flood plain analysis using ArcGIS, HEC-GeoRAS and HEC-RAS. This study was performed to map the floodplains of the Logan River between first dams and centre Street using ArcGIS. This was accomplished by creating river geometry in ArcMap, running a hydraulics model using the (HEC-RAS) Hydrologic Engineering Center's River Analysis System, analyzing the results, and creating floodplain maps in ArcMap. It was determined that many homes and a preschool would be inundated in the event of a $3500 \mathrm{cfs}$ flood. It was found from the analysis that there are many land parcels and public access locations that could potentially be inundated by water in the event of large flows in the Logan River, specifically in the area near Riverside Preschool.

\section{Objective}

The main objective of the present study is to analyze river flood. Under these objectives following studies were carried out: To find Depth of water level in the zone of Gurupura river using HEC-RAS Tools and to develop flood plain maps for section of the Gurupura river using HEC-RAS Tools.

\section{STUDY AREA AND DATA USED}

River Gurupura catchment is selected as study area in the present study which geographically lies between $12^{\circ} 50^{\prime} 57^{\prime \prime} \mathrm{N}$ longitude and $74^{\circ} 49^{\prime} 52^{\prime \prime}$ E latitude of Dakshina Kannada 
District. River Gurupura originates in Western Ghats, which ends at the Arabian Sea, south of Mangalore, Karnataka, India. The following data were used for the analysis:

i. $30 \mathrm{~m} \times 30 \mathrm{~m}$ resolution DEM is downloaded from SRTM.

ii. Cross section details of Gurupura River. is obtained from 30mx30m resolution DEM by using ARC GIS Tools.

iii. Discharge data of Gurupura River at Addoor station is collected from Central Water Commission, Sub Divisional Office Mangalore from the year 2003 to 2017.

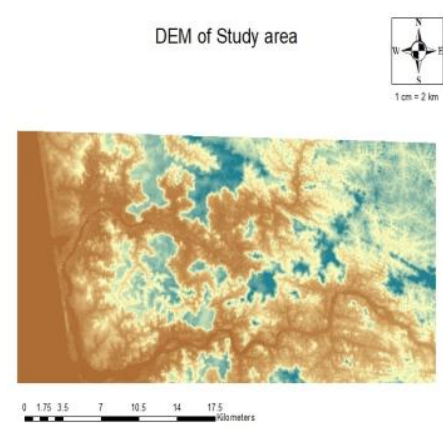

Figure-1: DEM of the study area

\section{METHODOLOGY}

The methodology includes Pre-processing of the data, Processing of the data and Post-processing of the results. The figure-2 represents the flow chart explaining the methodology used in the present analysis. Downloaded DEM of study area is re-projected with respect to WGS 84 / UTM Zone 44N projection.

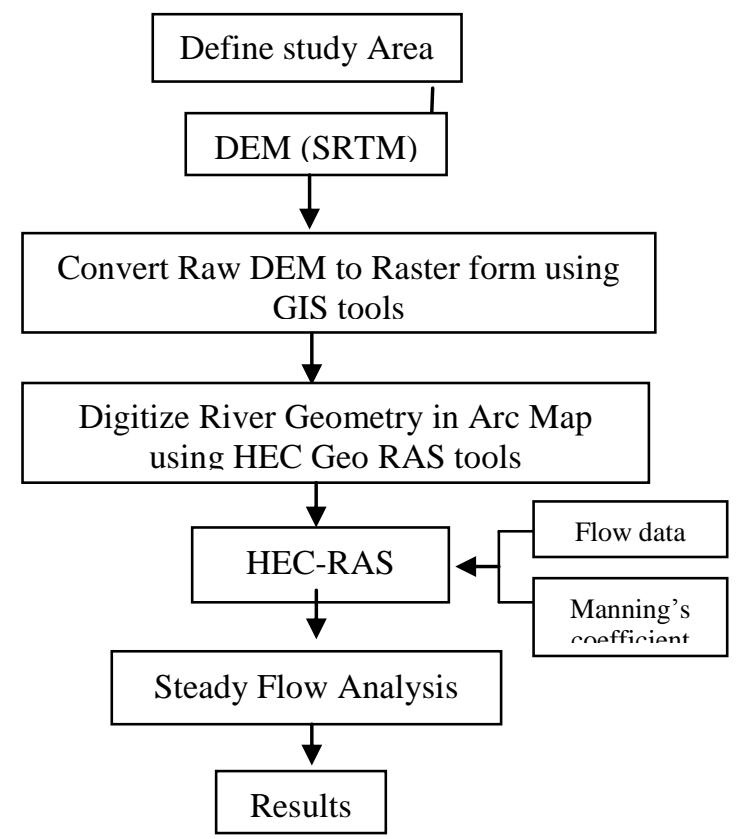

FIGURE-2: FLOW CHART OF STEADY FLOW ANALYSIS USING HEC-RAS MODELLING
The river geometry is created using ArcGIS tools and the cross-section of the river geometry is extracted using HECGeoRAS Tools. In this study, $17.97 \mathrm{~km}$ length of river is considered with 55 cross sections. Figure-3 represents River geometry and Cross sections. Figure-4 represents details of cross sections in imported into HEC-RAS. Steady flow analysis was carried out by using maximum discharge of 1171 $\mathrm{m}^{3} / \mathrm{sec}$, and Manning's coefficient as 0.035 . Normal depth is used for upstream and downstream boundary conditions and analysis is carried out.

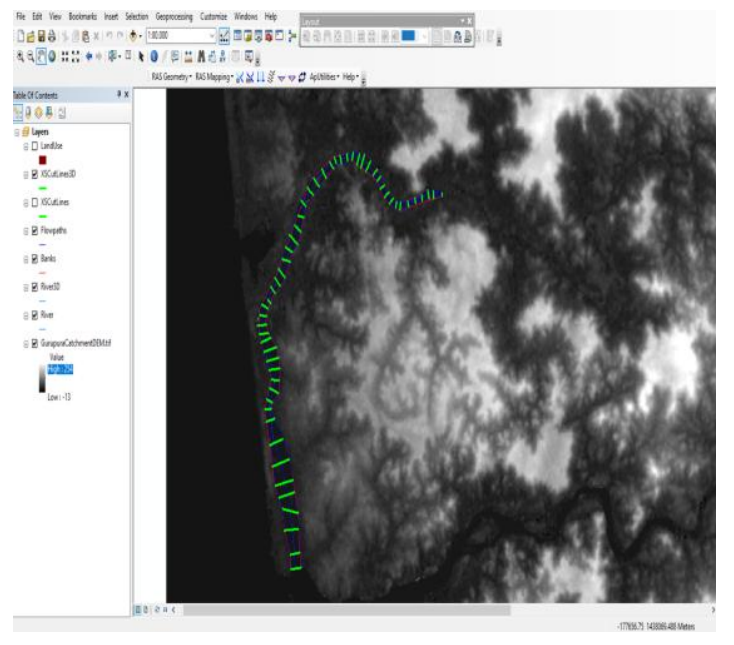

Figure-3: River geometry and Cross sections

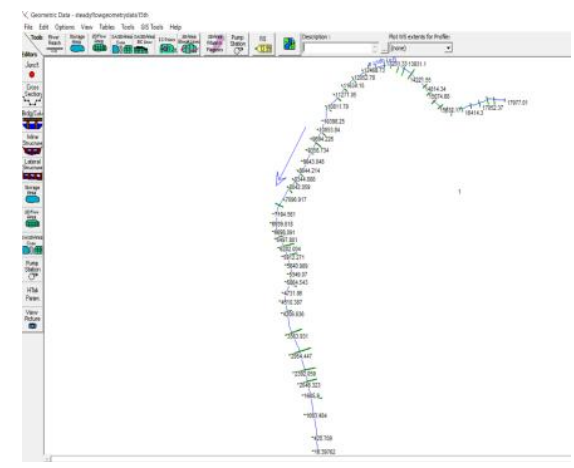

Figure-4: Detail of cross sections in HEC RAS.

\section{RESUlts}

The results of Steady flow analysis are in the form of water surface profiles, xyz perspective plots and summary table of output at each cross-section. Figure-5 represents Profile plotGurupura River for given maximum discharge of $1171 \mathrm{~m}^{3} / \mathrm{sec}$. From the results it is observed that depth of water level in the zone of Gurupura river varies from 0 to $8.4 \mathrm{~m}$. Figure- 6 represents XYZ Perspective plot for steady flow simulation of Gurupura River 


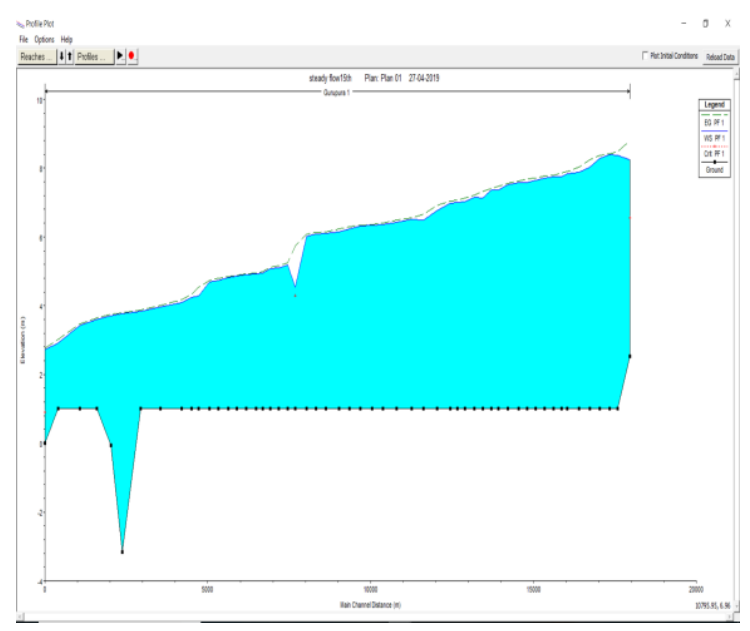

Fig. 5: Profile plot- Gurupura River for $Q=1171 \mathrm{~m}^{3} / \mathrm{sec}$

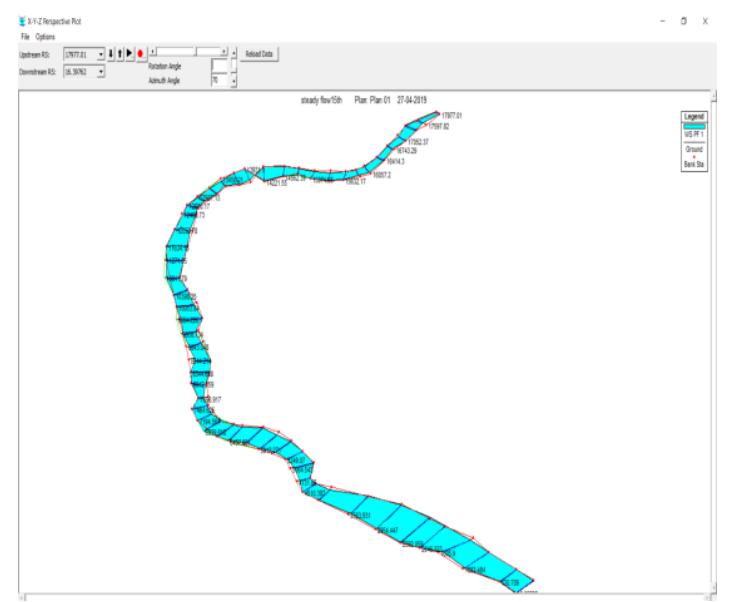

Figure-6: XYZ Perspective plot for steady flow simulation of Gurupura River

\section{CONCLUSION}

The purpose of this study was to determine the depth of water level in the zone of Gurupura river by steady flow analysis and to develop flood plain maps for the section of the Gurupura river using HEC-RAS tools. From the results it is observed that the rise in water level will be well within the river bank, hence it can be stated that the area near the river is safe from river flood effects.

\section{Acknowledgment}

We acknowledge Central Water Commission, Sub Divisional Office Mangalore for providing discharge data of Gurupura river at Addoor station. We also acknowledge US Army Corps of Engineers for providing HEC-RAS as open source software.

\section{References}

[1] Amina Azouagh, Rabei ElBardai, Ismael Hilal, Jamal Stitou el Messari (2018) "Integration of GIS and HEC-RAS in Floods Modeling of Martil River (Northern Morocco)", European Scientific Journal, ISSN: 1857 - 7881 (Print) e - ISSN 18577431, Vol.14, , No.12, Doi: 10.19044/esj.2018.v14n12p130,April 2018.

[2] Anant D. Patel, Dhruvesh P. Patel, Indra Prakash (2016) "Flood Modelling Using HEC-RAS And Geo-Informatics Technology In Lower Reaches Of Shetrunji River, Gujarath, India", National Conference on Water Resources \& Flood Management with special reference to Flood Modelling October 14-15, 2016 SVNIT Surat.

[3] Chandresh G. Patel, Pradip J. Gundaliya (2016) "Floodplain Delineation Using HECRAS Model-A Case Study of Surat City", Open Journal of Modern Hydrology, 2016, 6, 34-42, $25^{\text {th }}$ January 2016.

[4] Darshan J Mehta Dr S.M. Yadav \& Mrs. Sahita I Waikhom (2017) "HEC-RAS flow analysis in the river TAPI"

[5] Eric Tate, David Maidment, (1999) "Floodplain Mapping Using HEC-RAS and ArcView GIS" Bureau of Engineering Research, The University of Texas at Austin, J.J. Pickle Research Campus Austin, TX 78712-4497.

[6] Goodell C, Warren, "Flood inundation mapping using HEC RAS" west consultants, $260125^{\text {th }}$ St SE. Suite 450 ,salem, OR 97302.

[7] Hesham Ezz(2017) "Integrating GIS and HEC-RAS model assiut plateau runoff" National research centre, Bohouth St., dokki ,Egypt.

[8] Kedric Curtis, Josh Hogge, Jordan Jarrett, Jared Justensen (2016) "Logan river flood plain analysis using ArcGIS, HECGeoRAS and HEC-RAS" Utah water research laboratory. 